\title{
Environmental Impact of Services Trade: New Evidence from African Countries
}

\author{
Kabiru Hannafi Ibrahim ${ }^{1,2}$, Dyah Wulan Sari ${ }^{1}$, Rossanto Dwi Handoyo ${ }^{1 *}$ \\ ${ }^{1}$ Faculty of Economics and Business, Universitas Airlangga, Surabaya Indonesia \\ ${ }^{2}$ Faculty of Arts, Social and Management Sciences, Federal University, Birnin Kebbi Nigeria
}

Received: 26 November 2020

Accepted: 15 March 2021

\begin{abstract}
In trade-environment literature, increasing concern has been more focused on the goods trade and environment nexus with less focus on services. To this end, within the context of the Environmental Kuznets Curve (EKC) hypothesis, this study explores different channels through which services trade affects environmental pollution $\left(\mathrm{CO}_{2}\right)$. The study decomposed the effect of trade into the scale, technique, and composition effects in a panel of 47 African countries. Finding from the dynamic GMM estimate revealed that the scale effect increases $\mathrm{CO}_{2}$ emissions and degrades the environment. The technique effectively reduces $\mathrm{CO}_{2}$ emissions which is only temporary as there is evidence of $\mathrm{N}$-shaped nexus between GDP and $\mathrm{CO}_{2}$ emissions. Moreover, trade statistically and significantly increases $\mathrm{CO}_{2}$ emissions and there is no evidence of a turning point in the trade and $\mathrm{CO}_{2}$ emissions nexus. Energy and composition effects were found to increase emissions. Furthermore, the result indicates the existence of the pollution haven hypothesis (PHH) and there is no robust evidence supporting the factor abundance effect. There is also evidence of the harmful mediation effect of trade through energy intensity as it increases $\mathrm{CO}_{2}$ emissions. In line with the study findings, policy recommendations were made to mitigate the harmful environmental effect of growth and services trade in African countries.
\end{abstract}

Keywords: environmental pollution $\left(\mathrm{CO}_{2}\right)$, services trade, EKC hypothesis, dynamic GMM panel

\section{Introduction}

Environmental preservation and international trade are the two major issues related to human well-being and development [1]. This has generated a looming debate on the impact of trade on environmental quality. This debate has generated more heat than light as noted by [2]. Empirically, studies have thoroughly investigated the goods and overall trade impact on

*e-mail: rossanto_dh@feb.unair.ac.id the environmental quality with little focus on the services. Therefore, a separate investigation of the environmental consequences of services trade is still unexplored. Our main objective in this study is to investigate the direct and indirect effect of services trade liberalization on environmental quality in the context of African countries. To achieve this objective, we used the Environmental Kuznets Curve (EKC) model and decomposed the trade effect into the scale, technique, and composition effects. This is because the environmental impact of free trade can be studied using this model while decomposing the effect of trade into scale, technique, and composition effects. The scale 
effect as elaborated by [2] shows the effect of increase economic activities (GDP) on carbon emissions. While the technique effect refers to the gainful effect of increased income on carbon emissions necessitated by strict environmental regulations and people's demand for a cleaner environment. The composition effect, on the other hand, is determined by the comparative advantage derived from trade and it refers to the effect of change in the composition of output. The composition effect can assert a positive or negative effect on environmental pollution depending on the resource endowed by the country. Through the scale, technique, and composition effects, trade could affect the environment, this is because trade could increase income, productive activities, and composition of productive inputs which also increase emissions. A study by [2] among others, for instance, has found a positive scale effect, negative technique effect, and negative composition effect based on $\mathrm{SO}_{2}$ data. While decomposing trade effect into scale, technique, and composition, most empirical studies report mixed findings for the goods and overall trade impact on the environment. The environmental impact of services trade may be different owing to the different modes of service supply. Therefore, there is a need to investigate the specific role of services in generating or mitigating $\mathrm{CO}_{2}$ emissions.

Examining the impact of services trade on the environment is important owing to the growth in services over the last few decades. Growth in international trade has been much more attributed to the growth in the services sector and of services globally. Most countries, all over the world had experienced a tremendous increase in services trade. More importantly at the same time, countries around the world had also experienced environmental challenges owing to climate change, greenhouse gas emissions, air quality, and ozone layer depletion [3-5]. Services are an important input to different manufacturing industries and there is a need to understand its environmental consequences via the international trading system. As noted by [6] services help to reduce environmental degradation resulting from increased economic activities, though some services were found to increase emissions. For instance, in 2013 the disaggregated GHG emissions in Africa show that transport services account for $42 \%$ of the total GHG emissions which exceeds the global average [7]. In African countries, services trade has increased rapidly which cannot only be a driver of economic expansion but also a means of reducing emissions as most services are believed to be environment friendly. Theoretically, the turning point of the EKC is achieved by a transition from industry to services, so also services trade can play a role in reducing countries' environmental degradations. In African countries that are mostly developing the impact of services trade on the environment may differ from the notion that services have a beneficial effect on environmental quality. This is because [8] have noted that foreign trade has a detrimental impact on the environment in developing countries. With this background it is debatable to conclude on the environmental impact of services trade in African countries. Therefore, this debate can only be clear via an empirical study of the services trade impact on environmental quality.

In African countries, there are alarming environmental issues that range from oil pollution, energy, air pollution, water pollution, loss of biodiversity. The continent is also faced with the problem of rising population, poverty, hunger, illiteracy, and political uprising. This has made the continent remained underdeveloped and more susceptible to environmental degradation. Despite these problems, the continent's contribution to global emissions has remained low below $5 \%$ of the global $\mathrm{CO}_{2}$ emissions [9]. As a result of the low contribution to global emissions by the continent, the environmental consequences of free trade had been largely ignored by both researchers and policymakers in the continent. Therefore, there is a need to understand the forces behind environmental degradation in African countries by taking the specific role of services trade. This is because the continent is developing, more open to foreign trade, and also facing many environmental challenges which may be the result of market opening and other impending factors related to human activity. This is because [10] in his speech on the Perspective on Global Warming mentioned that "human activity is a significant contributor to climate change" which can cause $\mathrm{CO}_{2}$ emissions and environmental degradation.

With this in mind, therefore, this study contributes to the literature of trade and environment in many ways. Firstly, there is little emphasis given by researchers to services trade and the environment nexus. In this vein, our study contributes to the debate of trade and environment by solely investigating the effect of services trade on the environment in African countries. To the best of our knowledge, we are first to consider such an impact in the context of African countries. Secondly, the study also recognized the role of the turning point in the trade-environment nexus which has not been investigated by any empirical study in the context of African countries. This is important because trade may assert a different effect on the environment at a different level of trade openness. For instance, at a low level of openness, trade may be detrimental to the environment while at an advanced level it might have a beneficial effect resulting from technology spillover. So also if at a low level of openness, trade benefits the environment, it may degrade the environment at a high level because of pollution haven effect. Thirdly, we also incorporated GDP cubic components into the model of ECK to determine whether the first turning if any, is only temporary. To our knowledge and search for literature, this has not been investigated by any empirical study using a panel of African countries. Fourthly, the study also contributes to the existing knowledge by applying a new trade openness measure proposed by [11]. Besides, unlike previous studies, that 
measure services openness by only considering cross border services i.e. modes 1 and 2 . In constructing our services trade openness we incorporate all modes of services supply to have a broader measure of services trade openness. Fourthly, we considered the indirect channels via which trade can affect the environment by decomposing trade effect into the scale, technique, and composition effects. Lastly, we also investigate the pollution haven hypothesis (PHH) effect of trade based on income and factor abundance comparative advantage which has never been investigated by any empirical study in the context of African countries.

\section{Literature Review}

On the theoretical ground, the EKC hypothesis postulate that at the initial stage of development increased income is positively correlated with environmental pollution and after reaching the threshold point, environmental quality improves with further increase in per capita income [12]. Studies have questioned whether this threshold can be attained domestically or by transferring pollution to poor and developing countries $[13,14]$ in which case developing countries will become a pollution haven. In this case, therefore, even EKC explained the $\mathrm{PHH}$ in which advanced countries use trade as a means of moving their polluting industries to poor and developing countries. The optimism and the extent to which EKC can explain the transfer of pollution from developed to developing countries is not well justified [15]. The PHH, therefore, described a scenario in which trade openness improves the environment in some open countries and degraded it in other countries [16]. Another hypothesis based on factor abundance postulates that resources owned by countries are the main determinants of trade and environmental pollution [17]. According to this hypothesis, developed countries with abundant capital will become dirtier as they possessed a comparative advantage in capital-intensive export and production. While labour abundance developing countries will become cleaner as they explore comparative advantage in labour-intensive export and production. This hypothesis, therefore, operates in contrast to the PHH. The present study will focus on investigating the impact of trade on the environment within the context of the theoretical underpinning of the above theories more especially the EKC hypothesis. Many empirical studies applied the EKC model while investigating the environmental impact of free trade and the extent to which countries are becoming pollution haven resulting from trade openness. These studies have reported mixed findings which may be due to the use of different methodologies, model specification problems, and the way the trade openness is measured.

On the empirical ground, studies on the environmental impact of services trade are scarcer, the few available works of literature include; [18-20] who find that commercial services trade, financial services trade, and broader services trade reduces carbon emissions while GDP, energy consumption, renewable energy, and industrialization increase carbon emissions in 25 major developing countries, BRIC and China. A cross-country analysis by [21] observed that services trade increases $\mathrm{CO}_{2}$ emissions and reduces $\mathrm{SO}_{2}$ emissions. Other empirical studies [22-28] have confirmed the beneficial effect of mode 3 services supply (FDI) on the environment as it reduces $\mathrm{CO}_{2}$ emissions. On the contrary [20-30] have found mode 3 services to increase $\mathrm{CO}_{2}$ emissions and detriment the environment.

The few available literatures in the context of African countries include; [27, 31-34], which finds trade openness, GDP, energy consumption, and capitallabour ratio to increase $\mathrm{CO}_{2}$ emissions and reduce environmental quality. A study by [35] reports that in both the short-run and long-run trade openness, GDP, and renewable consumption asserts asymmetric effect on $\mathrm{CO}_{2}$ emissions in Nigeria and South Africa. In the context of South Africa [36] observed that trade oneness, human capital, and renewable energy consumption improve environmental quality by reducing ecological footprint while GDP degrades the environment by increasing ecological footprint. Empirical findings by [37] revealed no significant effect of democracy on $\mathrm{CO}_{2}$ emissions while globalization reduces $\mathrm{CO}_{2}$ emission and energy use increases emissions and degrade the environment in South Africa. An empirical finding by [38] established that Africa's regional trade has contributed to reducing $\mathrm{CO}_{2}$ emissions and $\mathrm{PM}_{10}$ in the continent. A study by [23] revealed that trade and capital stock increase $\mathrm{CO}_{2}$ emissions while GDP decreases $\mathrm{CO}_{2}$ emissions in Morocco. A study by [39], observed that trade openness decreases $\mathrm{CO}_{2}$ emissions while GDP, energy use, and urbanization increase emissions and degrade environmental quality in OPEC member countries. In the case of Nigeria [40] has found no evidence of trade effect on $\mathrm{CO}_{2}$ emissions while GDP increases emissions and that energy consumption, manufacturing value-added reduces carbon emissions. In another study [41] revealed that GDP increases $\mathrm{CO}_{2}$ emissions while renewable energy consumption reduces emissions in Nigeria.

Other studies used heterogeneous panels and explore the role of trade in generating environmental pollution. These studies include; [42, 43] who observed trade openness to increases $\mathrm{CO}_{2}$ emissions and degrades the environment. So also [44] reports that trade openness, GDP, and capital labour-ratio significantly influence carbon emissions. Studies by $[45,46]$ also revealed that trade and GDP degrade the environment while democratic governments improve environmental quality by reducing emissions and increasing air quality. In another study by [47], democracy was found to improve environmental quality in the short-run by reducing $\mathrm{CO}_{2}$ emissions while energy consumption degrades the environment by increasing $\mathrm{CO}_{2}$ emissions. 
In the context of Iran's trade with the Organization of Economic Cooperation and Development (OECD), Middle East, and East Asian countries [48] report that emissions have increased in Iran resulting from its trade with these regions. A recent study by [49] has found trade, energy efficiency, and renewable energy to reduce emissions while GDP and industrialization increase GHG emissions. Another study [50] observed that for the global sample and low-income countries trade degrade the environment while for high-income countries it improves the environment by reducing $\mathrm{PM}_{10}$.

In the context of developed countries studies have also established evidence of the beneficial and detrimental effect of trade on the environment. In the case of the U.S [51] find no evidence of trade impact on toxic releases while a study by [30] report that trade openness and capital-labour ratio contribute to reducing emissions and that GDP, energy consumption increase carbon emissions. In another study, [52, 53] revealed that trade openness, GDP, and energy consumption increases $\mathrm{CO}_{2}$ emissions in Turkey. For the developing countries sample, a study by [54-56] reports that trade and economic globalization reduces $\mathrm{CO}_{2}$ emissions. Studies by $[28,29,57,58]$ indicate that trade openness, GDP, energy consumption industrialization are detrimental to the environment. Findings by [59, 60] show that trade and renewable energy reduced $\mathrm{CO}_{2}$ emissions and improve environmental quality in China, BRICS, and N-11 countries. Contrarily, [61, 62] show no evidence of trade effect on $\mathrm{CO}_{2}$ emissions while GDP and energy consumption increases $\mathrm{CO}_{2}$ emissions in the case of Pakistan and India. In the case of China and Indonesia $[63,64]$ observed that trade, energy use, and industrialization increase emissions while GDP growth was found to decrease emissions and improve environmental quality.

Some empirical studies have demonstrated the PHH effect using the input-output (I-O) model and econometric approach in the context of Africa and other regions. For instance, [15]'s findings revealed that U.S and U.K as advanced countries use trade as a mechanism to transfer their polluting industries to the South African Customs Union (SACU) countries. Similarly, [65] has found that the net $\mathrm{CO}_{2}$ emissions transfer to China has resulted from its trading activities with Western Europe, North America, and other developed countries whereas its emissions outflow embedded in trade are transfer to Sub-Saharan Africa, America, and South Asia. Using computable general equilibrium [66] reports that advanced countries tend to shift their pollution to developing countries. A study by [25] confirmed that developed countries used to trade as a means of transferring their pollution to developing countries. [67], show that trade has contributed toward net emissions outflow in the Chinese Hebei province. A study by [68] supported the existence of PHH in China's domestic trade. Similarly, [69] revealed that a bulk of Beijing's fuel-related mercury pollutions were outsourced through trade. A study by [70] show that China's trade with "Belt and Road Initiative" countries has resulted in the concentration of China's export toward resource-intensive industries and increase pollution.

\section{Material and Methods}

\section{Model Specification}

To examine the environmental impact of services trade, we follow empirical literature and incorporated variables related to the scale, technique, and composition effects. Besides, we augmented interaction terms between the explanatory variables into the function of the $\mathrm{CO}_{2}$ emissions to verify the existence of income and factor endowment PHH. We formulate an empirical model within the context of standard EKC hypothesis with unobserved panel specification of the following form:

$$
\begin{gathered}
\operatorname{lnCO} O_{2 i t}=\lambda_{0}+\lambda_{1} \operatorname{lnGDP} P_{i t}+\lambda_{2} \operatorname{lnGDP_{it}}{ }^{2}+\lambda_{3} \operatorname{lnGDP_{it}}{ }^{3} \\
+\lambda_{4} \ln S T O_{i t}+\lambda_{5} \operatorname{lnSTO} O_{i t}{ }^{2}+\lambda_{6} \ln K L_{i t}+\lambda_{7} \ln E I_{i t} \\
+\lambda_{8} \ln G D P_{i t} * \ln S T O_{i t}+\lambda_{9} \ln K L_{i t} * \ln S T O_{i t} \\
+\lambda_{10} \ln E I_{i t} * \ln S T O_{i t}+\lambda_{11} \ln A G R_{i t}+\lambda_{12} \ln I N D_{i t} \\
+\lambda_{13} \ln S E R_{i t}+\lambda_{14} \ln P O L_{i t}+\psi_{i}+\eta_{t}+\varepsilon_{i t}
\end{gathered}
$$

...where: ${ }_{i}=1,2, \quad 3 \ldots \ldots . \mathrm{N}$ represent the country dimension in the cross-section, ${ }_{t}=$ is the time period. All the variables were transformed into a natural log. $\mathrm{CO}_{2}$, (i.e. emissions measured in per capita metric tons) is a measure of environmental quality. GDP, is the real $G D P$ per capita which measures the scale effect. If the coefficient of GDP is positive and significant we verify the scale effect. $R G D P^{2}$, is squared of $G D P$ which measures the technique effect and the existence of the EKC hypothesis. The negative and statistically significant coefficient of GDP squared verify the technique effect and the existence of the EKC hypothesis. GDP $P^{3}$, is the $G D P$ cubic component introduced to verify whether the first turning point of EKC if exists is only temporary. Positive and statistically significant $G D P^{3}$ will validate the existence of N-shape EKC. STO, is the services trade openness expected to assert either a positive or negative effect on emissions. $S T O^{2}$, is the squared of trade openness, introduced to verify the non-linear nexus between trade and environmental pollution. Positive $S T O$ and negative $S T O^{2}$ would verify the hypothesis that, at a lower level of openness, trade may be harmful to the environment, and after reaching an advanced stage of trade liberalization it may have a beneficial effect on the environment as a result of technology spillover. $K L$, is the capita-labour ratio which measures the composition effect. Positive and statistically significant $K L$ would support the hypothesis that trade alters the composition of the industry towards dirtier production and increase pollution. $E I$, is the energy intensity measuring 
the energy effect and is hypothesized to increase emissions.

The interactions among the variables of interest are introduced to measure and verify the existence of income and factor endowment PHH and to verify whether trade openness has enabled the use of energyefficient technology in mitigating carbon emissions. A positive and statistically significant coefficient of GDP * STO would validate the hypothesis that developing countries like Africa are pollution havens in which case developed countries used trade openness to transfer their pollution to the continent. A negative and statistically significant coefficient $K L * S T O$ would support the hypothesis that trade allows labour abundance countries like Africa to specialize in labourintensive production and exportation which is less polluting. A negative coefficient $E I * S T O$ would provide evidence that trade allows for the use of energy-efficient equipment that is less polluting. Other control variables include; Polity $P O L$ which measures the level of a country's democracy and expected to lower emissions. $A G R, I N D$ and POLSER are the agriculture, industry, and services value-added as \% of GPD with an a priori expected sign of negative, positive, and negative. $\lambda_{1} \ldots . . . \lambda_{14}$, are the parameters to be estimated concerning the explanatory variables. $\varepsilon_{i t}$, is the error term that is assumed to be independently and identically distributed. The term $\psi_{i}$ is the unobserved effect specific to an individual country and doesn't change with time, $\eta_{i}$ is the time-specific effect that is time-variant and is common to all individual countries.

Model (1) can simply be estimated using Ordinary Least Square (OLS) or restricted OLS provided that across countries, the individual effects $\left(\psi_{i}\right)$ are constant and there is no time effect such that $\left(\eta_{t}=0\right)$. If country effects $\left(\psi_{i}\right)$ are not constant but random with disturbances $\left(œ_{i}\right)$ and there is no time effect $\eta_{t}=0$, such that $\left(\psi_{i}=œ_{i}+\eta_{t}\right)$. Where the expectations of $œ_{i}$ are zero i.e. $E\left(œ_{i}\right)=0$ with variance $\left(œ_{i}\right)=\sigma_{\propto}{ }^{2}$ and covariance $\left(\varepsilon_{i}, œ_{i}\right)=0$. With this Model (1) can be estimated using Random Effect (RE) models or Generalized Least Squares (GLS). If we further assume country effects $\left(\psi_{i}\right)$ to be constant and not equal across countries such that $\left(\psi_{i}=\eta_{t}\right.$ and $\left.\eta_{t} \neq 0\right)$ then Model (1) can be estimated using the fixed effect (FE) model.

Given that most economic variables and their associations are dynamic and the potential endogeneity that cannot be addressed using POLS, FE, and RE models, we employed the dynamic panel data modelling. This approach is based on an estimate known as the Generalized Method of Moment (GMM) proposed by [71]. In a dynamic model the environmental pollution and its determinants which changes across time and space can be specified as follows:

$$
\begin{gathered}
\ln C O_{2 i t}=\lambda_{0}+\lambda^{\prime} \ln C O_{2 i t-1}+\delta^{\prime}{ }_{1} \ln X_{i t}+\delta^{\prime}{ }_{2} \ln Y_{i t} \\
+\psi_{i}+\eta_{t}+\varepsilon_{i t}
\end{gathered}
$$

...where $\mathrm{CO}_{2 i t}$, is the environmental quality indicator measured as carbon emissions. $C O_{2 i t-1}$, is the lagged dependent variable introduce to capture the dynamic properties of the model. $\lambda^{\prime}$, is the adjustment coefficient. $X_{i t}$, and $Y_{i t}$ are the vectors of explanatory and control variables as defined in Model (1). $\psi_{i}$, is the countryspecific fixed effects, $\eta_{t}$ is the time trend which captures global shocks, and $\varepsilon_{i t}$ is the idiosyncratic twoway error component; $i=1,2 \ldots N$ are the number of countries and $t=1,2, \ldots, T$ is the number of years. To eliminate the country effect in Model (2) Arellano and Bond's estimation procedures required taking the first difference of Model (2) as follows;

$$
\begin{gathered}
\ln \Delta C O_{2 i t}=\lambda^{\prime} \ln \Delta C O_{2 i t-1}+\delta^{\prime}{ }_{1} \ln \Delta X_{i t}+\delta^{\prime}{ }_{2} \ln \Delta Y_{i t} \\
+\Delta \mathrm{\eta}_{t}+\Delta \varepsilon_{i t}
\end{gathered}
$$

...where: All variables are as defined in Model (2) except here they all entered the model as first differences. By differencing the individual effect is now automatically eliminated in Model (3). While differencing to remove the individual effect, the within estimator is also biased because the differences in the lagged dependent variable $\left(\triangle \mathrm{CO}_{2 i t}=\mathrm{CO}_{2 i t-1}-\mathrm{CO}_{2 i t-2}\right)$ are also correlated with the differences in the random disturbance term $\left(\Delta \varepsilon_{i t}=\varepsilon_{i t}-\varepsilon_{i t-1}\right)$. As a result, [72] pointed out that with a small-time period and persistent time series the first difference GMM estimator may likely be biased because of weak instruments provided by lagged levels. If the first difference estimator is biased because of weak instrumentation resulting from the persistency of the lagged dependent variable, the most appropriate estimation technique is the system GMM estimator proposed by [72]. Despite the weakness of the first difference estimator, it is still considered relevant and less biased if the persistency of the data is weak. In this case, the first difference GMM would be more appropriate as it would possess some efficiency gains compared to the system GMM estimator. Owing to the efficiency gains from using either the difference or system GMM, we used the [73]'s rule of thumb to decide on the most appropriate estimator for our data set.

\section{Data Source and Variable Measurement}

The study utilized data for a sample of 47 African countries obtained from the World Bank, World Development Indicators, and the Polity IV Project at the University of Maryland over the period 2000-2014. The choice of this period is motivated by data availability and to capture the period African countries embarked on a massive trade liberalization strategy.

We construct a measure of services trade openness based on the [11]'s approach. [11], have argued that an economy is considered open if it has a high trade/GDP ratio and considerable trade share relative to the rest of the world. Our services openness measure based on [11]'s approach is given by: 


$$
S T O_{i}=\frac{(\mathrm{SX}+\mathrm{SM})_{i}}{1 / n \sum_{j=1}^{n}(S X+S M) j} *(\mathrm{SX}+\mathrm{SM})_{i} / G D P_{i}
$$

...where: ${ }_{i}$ stand for country subscript. ${ }_{i}$ stands for trading partners or the rest of the world. STO, is the composite services trade openness, which is a composite measure of country 's trade/GDP ratio and its trade share relative to the rest of the world. $S X$ and $S M$ are country ${ }_{i}$ s services export and import. $n$ denotes the number of countries.

This measure has an advantage over the trade/ GDP ratio more especially in cross-country and panel studies. In cross-country analysis, a high trade/GDP ratio may not reflect the actual degree of countries' openness. This is because smaller countries may tend to have a high trade/GDP ratio for a reason that their GDP is small relative to their trade. While larger economies whose trade constitutes a smaller fraction of their economic size would tend to have a low trade/ GDP ratio even though, they are significant contributors to the global trade [11]. Also, we adopted the definition of services trade provided by the General Agreement on Trade in Services (GATS) in constructing the openness of our servicer trade. Therefore, our constructed STO is broader services openness that includes all modes of services supply as defined by GATS which include mode 1: cross border services trade, mode 2: consumption abroad, mode 3: commercial presence (FDI), mode 4: movement of the professional workers to provide services in the territory of another country. Data for remittance received and paid by African countries was used to proxy for services supplied via the movement of professional workers. To this end, in this study, $S X$ and $S M$ are broad services exports and imports that include all modes of services supply.

$\mathrm{CO}_{2}$ emissions in metric tons per capita represent the emission that every citizen is responsible for. GDP is measured as real per capita gross domestic product estimated at constant 2010 US\$. The Capital-labour ratio is the ratio of capital stock to the economically active population (ages 15-65). Energy intensity presents the energy used per unit of output computed based on the level of primary energy (MJ/\$2011 PPP GDP). Agriculture, industry, and services are sectoral valueadded as a percentage of GDP. Democratic government is measured by the polity index with a score ranging from -10 (highly autocratic) to +10 (highly democratic).

\section{Results and Discussion}

The correlation coefficient of the dependent variable and GDP is 0.91 which is strong and highly significant at less than 1 percent level. Our analysis shows that services trade openness, energy intensity, services value-added, and polity are weakly but significantly correlated with the dependent variable with a correlation coefficient of $0.27,-0.43,0.21$, and -0.08 respectively. Our analysis further demonstrates that the capital-labour ratio and agriculture value-added are also strongly correlated with the dependent variable with 0.87 and 0.82 coefficients while industry value-added is moderately correlated with the dependent variable with a 0.58 coefficient. The correlation among the regressors does not reveal a high correlation that may result in a multicollinearity problem to our empirical analysis. We further conducted the variance inflation factor (VIF) test, to again check for multicollinearity. The result of the test for all the estimated linear and polynomial models also revealed that our estimated models did not have multicollinearity. This is because VIF values are all below the standard required value of 6 and the threshold value of 10. The estimated VIF values for the estimated models (1)-(9) lies between 2.55 and 3.98.

For our empirical analysis, we used [73] rules of thumb to decide on the difference and system GMM estimate. The rule of thumb is based on the estimate of the dynamic version of POLS, FE, and first difference GMM. The estimate of the lagged dependent variable from the pooled OLS is considered as an upper bound estimate while that of FE is a lower bound estimate. According to [73] if the estimate of the lagged dependent variable from the difference GMM is below the FE estimate, the system GMM should be used because the first difference estimate would be downward biased resulting from weak instrumentation [72]. If the first difference estimate is above the FE estimate, then the difference GMM should be used because it would provide a consistent, efficient, and less biased estimate. This rule of thumb when applied to our data has proven the need to use first difference GMM instead of system GMM. This is because we find that the lagged dependent variable of the difference GMM estimate is above that of the FE estimate. Therefore, in our case, the difference GMM should be preferred to system GMM as it is more appropriate for our data set. Table 1 reports the result of the two-step GMM estimate, we chose a two-step estimate because theoretically, the estimate relied on the best balancing matrices that are more efficient than the one-step estimate.

The estimated parameters in Table 1 were in the natural $\log$ and should be interpreted as elasticities. We estimated nine dynamic models that are different in two dimensions i.e. linear and cubic polynomial models for more robustness of the empirical findings. The $p$-values of AR(2), Sargan and Hansen tests show that there is no second-order serial correlation, and our instrument set is valid. From estimates (1)-(9) the coefficients of the lagged dependent variable are positive and highly statistically significant at less than $1 \%$ level. This finding suggests that the current emissions are affected by past emissions levels. This finding is supported by $[22,31,57]$ among others who all found the current emissions to be positively influenced by past emissions. The baseline model (1) tells that except $K L * S T O$ all our variables of interest asserts a statically significant 
Table 1. Dynamic GMM estimate for services trade effect on environmental pollution $\left(\mathrm{CO}_{2}\right)$.

\begin{tabular}{|c|c|c|c|c|c|c|c|c|c|}
\hline & (1) & (2) & (3) & (4) & (5) & (6) & (7) & (8) & (9) \\
\hline L. $\ln \mathrm{CO}_{2}$ & $\begin{array}{c}0.694 * * * \\
(0.193)\end{array}$ & $\begin{array}{c}0.675^{* * *} \\
(0.134)\end{array}$ & $\begin{array}{c}0.635^{* * * *} \\
(0.114)\end{array}$ & $\begin{array}{c}0.606^{* * *} \\
(0.138)\end{array}$ & $\begin{array}{c}0.662 * * * \\
(0.115)\end{array}$ & $\begin{array}{c}0.611 * * * \\
(0.149)\end{array}$ & $\begin{array}{c}0.638^{* * *} \\
(0.163)\end{array}$ & $\begin{array}{c}0.690 * * * \\
(0.241)\end{array}$ & $\begin{array}{c}0.632 * * * \\
(0.178)\end{array}$ \\
\hline $\operatorname{lnGDP}$ & $\begin{array}{l}0.538 * \\
(0.283)\end{array}$ & $\begin{array}{l}0.593 * \\
(0.328)\end{array}$ & $\begin{array}{l}0.509 * \\
(0.307)\end{array}$ & $\begin{array}{c}0.537 * * \\
(0.270)\end{array}$ & $\begin{array}{c}0.515^{* *} \\
(0.202)\end{array}$ & $\begin{array}{l}0.523 * \\
(0.268)\end{array}$ & $\begin{array}{c}0.585^{* *} \\
(0.274)\end{array}$ & $\begin{array}{l}0.577 * \\
(0.328)\end{array}$ & $\begin{array}{c}0.517 * * * \\
(0.199)\end{array}$ \\
\hline $\operatorname{lnGDP} 2$ & $\begin{array}{c}-0.181^{* *} \\
(0.0796)\end{array}$ & $\begin{array}{c}-0.233^{* *} \\
(0.0952)\end{array}$ & $\begin{array}{c}-0.262^{* * *} \\
(0.0905)\end{array}$ & $\begin{array}{c}-0.222 * * \\
(0.0864)\end{array}$ & $\begin{array}{c}-0.220^{* *} \\
(0.0853)\end{array}$ & $\begin{array}{c}-0.270^{* *} \\
(0.112)\end{array}$ & & & \\
\hline $\operatorname{lnGDP} 3$ & $\begin{array}{l}0.0728 * \\
(0.0386)\end{array}$ & $\begin{array}{l}0.0824 * \\
(0.0464)\end{array}$ & $\begin{array}{l}0.0833^{*} \\
(0.0439)\end{array}$ & $\begin{array}{l}0.0710^{*} \\
(0.0371)\end{array}$ & $\begin{array}{c}0.0805 * * \\
(0.0350)\end{array}$ & $\begin{array}{l}0.0879 * \\
(0.0467)\end{array}$ & & & \\
\hline $\operatorname{lnSTO}$ & $\begin{array}{l}0.0175^{* *} \\
(0.00716)\end{array}$ & $\begin{array}{l}0.0234 * \\
(0.0139)\end{array}$ & $\begin{array}{l}0.0234 * \\
(0.0134)\end{array}$ & $\begin{array}{c}0.0137^{*} \\
(0.00700)\end{array}$ & $\begin{array}{c}0.0245 * * * \\
(0.00644)\end{array}$ & $\begin{array}{c}0.0134 * \\
(0.00804)\end{array}$ & $\begin{array}{c}0.0383 * \\
(0.0216)\end{array}$ & $\begin{array}{c}0.0117^{*} \\
(0.00683)\end{array}$ & $\begin{array}{c}0.0140 * \\
(0.00828)\end{array}$ \\
\hline $\operatorname{lnSTO}{ }^{2}$ & $\begin{array}{c}8.56 \mathrm{e}-05 \\
(0.000164)\end{array}$ & $\begin{array}{c}0.000563^{*} \\
(0.000301)\end{array}$ & $\begin{array}{c}0.000532 * * \\
(0.000270)\end{array}$ & $\begin{array}{c}0.000303 * * \\
(0.000126)\end{array}$ & $\begin{array}{c}1.17 \mathrm{e}-05 \\
(0.000201)\end{array}$ & $\begin{array}{l}0.000262 * \\
(0.000151)\end{array}$ & & & \\
\hline $\operatorname{lnKL}$ & $\begin{array}{l}0.227^{*} \\
(0.134)\end{array}$ & $\begin{array}{c}0.254^{* *} \\
(0.125)\end{array}$ & $\begin{array}{l}0.243^{*} \\
(0.139)\end{array}$ & $\begin{array}{l}0.247^{*} \\
(0.145)\end{array}$ & $\begin{array}{l}0.236^{*} \\
(0.131)\end{array}$ & $\begin{array}{l}0.216^{*} \\
(0.121)\end{array}$ & $\begin{array}{l}0.316^{*} \\
(0.170)\end{array}$ & $\begin{array}{c}0.436^{* *} \\
(0.214)\end{array}$ & $\begin{array}{c}0.877 * * \\
(0.371)\end{array}$ \\
\hline $\ln E I$ & $\begin{array}{c}0.598^{* * * *} \\
(0.166)\end{array}$ & $\begin{array}{c}0.593 * * * \\
(0.170)\end{array}$ & $\begin{array}{c}0.562 * * * \\
(0.187)\end{array}$ & $\begin{array}{c}0.701 * * * \\
(0.210)\end{array}$ & $\begin{array}{c}0.656 * * * \\
(0.176)\end{array}$ & $\begin{array}{c}0.641 * * * \\
(0.198)\end{array}$ & $\begin{array}{c}0.603 * * * \\
(0.190)\end{array}$ & $\begin{array}{c}0.538 * * \\
(0.258)\end{array}$ & $\begin{array}{c}0.583 * * * \\
(0.143)\end{array}$ \\
\hline $\operatorname{lnGDP} * \ln S \mathrm{TO}$ & $\begin{array}{l}0.0227 * \\
(0.0135)\end{array}$ & $\begin{array}{c}0.0232 * * * \\
(0.00827)\end{array}$ & $\begin{array}{c}0.0126^{*} \\
(0.00743)\end{array}$ & & $\begin{array}{l}0.0199 * \\
(0.0118)\end{array}$ & & $\begin{array}{l}0.128 * * \\
(0.0508)\end{array}$ & & $\begin{array}{l}0.0223 * \\
(0.0114)\end{array}$ \\
\hline $\operatorname{lnKL} * \ln S \mathrm{TO}$ & $\begin{array}{r}-0.00518 \\
(0.0155)\end{array}$ & $\begin{array}{r}-0.00970 \\
(0.0100)\end{array}$ & & & $\begin{array}{l}-0.00351 \\
(0.0144)\end{array}$ & & $\begin{array}{c}-0.0810^{*} \\
(0.0467)\end{array}$ & & $\begin{array}{c}-0.000438 \\
(0.0108)\end{array}$ \\
\hline $\operatorname{lnEI} * \operatorname{lnSTO}$ & $\begin{array}{c}0.0312 * * \\
(0.0144)\end{array}$ & & & & $\begin{array}{c}0.0478^{* *} \\
(0.0196)\end{array}$ & & $\begin{array}{c}0.105^{* * *} \\
(0.0348)\end{array}$ & & $\begin{array}{l}0.0295^{*} \\
(0.0170)\end{array}$ \\
\hline $\ln A G R$ & $\begin{array}{c}-0.0211 \\
(0.107)\end{array}$ & $\begin{array}{c}-0.00262 \\
(0.223)\end{array}$ & $\begin{array}{r}-0.0820 \\
(0.179)\end{array}$ & $\begin{array}{l}-0.121 \\
(0.185)\end{array}$ & & & $\begin{array}{c}-0.0268 \\
(0.167)\end{array}$ & $\begin{array}{c}-0.277 * * \\
(0.137)\end{array}$ & \\
\hline $\operatorname{lnIND}$ & $\begin{array}{l}0.00124 \\
(0.0773)\end{array}$ & $\begin{array}{c}0.0197 \\
(0.0758)\end{array}$ & $\begin{array}{l}0.00202 \\
(0.0614)\end{array}$ & $\begin{array}{c}0.298^{* *} \\
(0.136)\end{array}$ & & & $\begin{array}{l}0.0989 \\
(0.112)\end{array}$ & $\begin{array}{l}0.403 * \\
(0.218)\end{array}$ & \\
\hline $\operatorname{lnSER}$ & $\begin{array}{c}0.123 \\
(0.297)\end{array}$ & $\begin{array}{l}0.190^{*} \\
(0.106)\end{array}$ & $\begin{array}{c}0.300^{* *} \\
(0.127)\end{array}$ & $\begin{array}{l}0.336^{*} \\
(0.183)\end{array}$ & & & $\begin{array}{l}0.0326 \\
(0.139)\end{array}$ & $\begin{array}{l}0.0334 \\
(0.183)\end{array}$ & \\
\hline $\ln \mathrm{POL}$ & $\begin{array}{c}-0.209^{*} \\
(0.117)\end{array}$ & $\begin{array}{c}-0.340^{* * *} \\
(0.129)\end{array}$ & $\begin{array}{c}-0.315^{* *} \\
(0.129)\end{array}$ & $\begin{array}{c}-0.217 * * \\
(0.0876)\end{array}$ & & & $\begin{array}{c}-0.0683 \\
(0.0861)\end{array}$ & $\begin{array}{r}-0.0695 \\
(0.142)\end{array}$ & \\
\hline Sargan $\mathrm{p}$-value & $(0.560)$ & $(0.705)$ & $(0.693)$ & $(0.691)$ & $(0.389)$ & $(0.348)$ & $(0.325)$ & $(0.281)$ & $(0.143)$ \\
\hline Hansen p-value & $(0.629)$ & $(0.349)$ & $(0.282)$ & $(0.509)$ & $(0.473)$ & $(0.459)$ & $(0.314)$ & $(0.389)$ & $(0.552)$ \\
\hline $\mathrm{AR}(2) \mathrm{p}$-value & $(0.505)$ & $(0.624)$ & $(0.604)$ & $(0.238)$ & $(0.379)$ & $(0.405)$ & $(0.474)$ & $(0.465)$ & $(0.371)$ \\
\hline Observations & 539 & 536 & 536 & 523 & 534 & 534 & 536 & 536 & 516 \\
\hline
\end{tabular}

Note: The statistical significance of the estimates at $<1 \%,<5 \%$ and $<10 \%$ are denoted by $* * *, * *$, and $*$ respectively. Robust standard errors were in parenthesis except for Sargan, Hansen, and AR(2) which are p-values.

impact on $\mathrm{CO}_{2}$ emissions. There is strong evidence that GDP increases $\mathrm{CO}_{2}$ emissions in all estimated models. The result from the baseline model (1) suggests that a $1 \%$ increase in GDP is associated with a $0.538 \%$ increase in carbon emissions. This implies that the scale effect is observed in a panel of African countries. The technique effect measured by the squared of GDP is negative and statistically significant. The positive scale effect and the negative technique effect confirmed the presence EKC hypothesis. The coefficient of GDP cubic is positive and statistically significant in (1)-(6) estimates. This finding is a disproved to EKC hypothesis as obtained by the positive scale effect and negative technique effect. This implies that there is an N-shaped nexus between
GDP and emissions in African countries. Our finding is supported by recent studies like [40, 56, 58, 60].

Finding also revealed that an increase in trade openness deteriorates the environment by increasing $\mathrm{CO}_{2}$ emissions. From the baseline models (1) of Table 1 , the finding suggests that a $1 \%$ increase in trade openness increases carbon emissions by $0.0175 \%$. This finding is robust to different linear and cubic polynomial model estimates and supported by [18, 19, 21] among others. The non-linear component of trade openness is positive and statistically significant in most estimates. This implies a monotonic increase as there is no turning point for trade to decrease carbon emissions. A plausible explanation is that services flow especially 
of mode 3 come from less-advanced countries that have less sophisticated technology which increases $\mathrm{CO}_{2}$ emissions. This finding contradicts [43]'s finding who found an inverted U-shaped for trade-pollution nexus. The composition effects worsen the environment by increasing $\mathrm{CO}_{2}$ emissions. From the baseline model (1) a percentage increase in capital-labour ratio is associated with a $0.227 \%$ increase in $\mathrm{CO}_{2}$ emissions at less than $10 \%$ significance level. This finding is robust to different estimates in Table 1 and is supported by [27, 44] but contradicts [30] among others. Evidence revealed that emissions increases with an increase in energy intensity. From the baseline model, a 1\% increase in energy use is associated with a $0.598 \%$ increase in $\mathrm{CO}_{2}$ emissions. This finding is supported by many recent studies [18, 31, 60] and contradicts [40] among others. The estimated coefficient of energy use is high because over $90 \%$ of countries in Africa relied on conventional non-renewable energy sources [22] which significantly increases emissions. Since nonrenewable energy use dominates over renewable energy use, this implies more emissions with increased energy consumption.

The interaction term between trade and GDP which measures the $\mathrm{PHH}$ yields a positive and statistically significant coefficient in all estimates. This implies that African countries are pollution haven when open to foreign trade. This result confirmed that developed countries use trade as a means of transferring their polluting activities to African countries and this is supported by [25] but contradicts [49] who confirmed a negative but statistically insignificant effect of

Table 2. RE estimate for services trade effect on environmental pollution $\left(\mathrm{CO}_{2}\right)$.

\begin{tabular}{|c|c|c|c|c|}
\hline VARIABLES & (1) & (2) & (3) & (4) \\
\hline $\operatorname{lnGDP}$ & $\begin{array}{c}0.845^{* * *} \\
(0.0684)\end{array}$ & $\begin{array}{c}0.977 * * * \\
(0.0466)\end{array}$ & $\begin{array}{c}1.093^{* * *} \\
(0.117)\end{array}$ & $\begin{array}{l}1.042 * * * \\
(0.0224)\end{array}$ \\
\hline $\operatorname{lnGDP} 2$ & $\begin{array}{c}-0.0936^{* * *} \\
(0.0214)\end{array}$ & & & \\
\hline $\operatorname{lnGDP}{ }^{3}$ & $\begin{array}{c}0.0356^{* * *} \\
(0.0138)\end{array}$ & & & \\
\hline $\operatorname{lnSTO}$ & $\begin{array}{c}0.0264 * * * \\
(0.00888)\end{array}$ & $\begin{array}{c}0.0116^{*} \\
(0.00682)\end{array}$ & $\begin{array}{l}0.0121^{* *} \\
(0.00571)\end{array}$ & $\begin{array}{l}0.0118^{* *} \\
(0.00592)\end{array}$ \\
\hline $\operatorname{lnSTO}{ }^{2}$ & $\begin{array}{l}0.000800^{*} \\
(0.000461)\end{array}$ & & & \\
\hline $\operatorname{lnKL}$ & $\begin{array}{c}0.353 * * * \\
(0.0365)\end{array}$ & $\begin{array}{c}0.352 * * * \\
(0.0227)\end{array}$ & $\begin{array}{c}0.279 * * * \\
(0.0558)\end{array}$ & $\begin{array}{c}0.364 * * * \\
(0.0150)\end{array}$ \\
\hline $\ln E I$ & $\begin{array}{c}0.551 * * * \\
(0.0364)\end{array}$ & $\begin{array}{c}0.490 * * * \\
(0.0253)\end{array}$ & $\begin{array}{c}0.534 * * * \\
(0.0414)\end{array}$ & $\begin{array}{c}0.479 * * * \\
(0.0190)\end{array}$ \\
\hline $\operatorname{lnGDP} * \ln S \mathrm{TO}$ & $\begin{array}{c}0.0685^{* * *} \\
(0.0164)\end{array}$ & $\begin{array}{c}0.0708^{* * *} \\
(0.0166)\end{array}$ & & $\begin{array}{c}0.0807 * * * \\
(0.0203)\end{array}$ \\
\hline $\operatorname{lnKL} * \operatorname{lnSTO}$ & $\begin{array}{c}-0.0221 \\
(0.0138)\end{array}$ & $\begin{array}{c}-0.0239 * * \\
(0.0113)\end{array}$ & & $\begin{array}{c}-0.0279 * * \\
(0.0137)\end{array}$ \\
\hline $\operatorname{lnEI*} \operatorname{lnSTO}$ & $\begin{array}{c}0.0416 * * * \\
(0.0130)\end{array}$ & $\begin{array}{c}0.0562^{* * *} \\
(0.0109)\end{array}$ & & $\begin{array}{c}0.0628^{* * *} \\
(0.0103)\end{array}$ \\
\hline $\ln A G R$ & $\begin{array}{c}-0.192 * * * \\
(0.0430)\end{array}$ & $\begin{array}{c}-0.0999 * * * \\
(0.0227)\end{array}$ & $\begin{array}{c}-0.0588 * * \\
(0.0245)\end{array}$ & \\
\hline $\operatorname{lnIND}$ & $\begin{array}{l}0.00349 \\
(0.0325)\end{array}$ & $\begin{array}{c}0.0190 \\
(0.0225)\end{array}$ & $\begin{array}{l}0.0414 * \\
(0.0216)\end{array}$ & \\
\hline $\operatorname{lnSER}$ & $\begin{array}{c}0.164 * * \\
(0.0689)\end{array}$ & $\begin{array}{c}0.243 * * * \\
(0.0498)\end{array}$ & $\begin{array}{c}0.229 * * * \\
(0.0612)\end{array}$ & \\
\hline $\ln \mathrm{POL}$ & $\begin{array}{c}0.0363 \\
(0.0232)\end{array}$ & $\begin{array}{c}0.0375 \\
(0.0274)\end{array}$ & $\begin{array}{c}0.0440 \\
(0.0326)\end{array}$ & \\
\hline Constant & $\begin{array}{c}-1.052 * * * \\
(0.0377)\end{array}$ & $\begin{array}{c}-1.137 * * * \\
(0.0304)\end{array}$ & $\begin{array}{c}-1.152 * * * \\
(0.0227)\end{array}$ & $\begin{array}{c}-1.162 * * * \\
(0.0124)\end{array}$ \\
\hline Time effect & Yes & Yes & Yes & Yes \\
\hline Observations & 642 & 642 & 642 & 642 \\
\hline $\mathrm{R}^{2}$ & 0.799 & 0.749 & 0.726 & 0.741 \\
\hline
\end{tabular}

Note: The statistical significance of the estimates at $<1 \%,<5 \%$ and $<10 \%$ are denoted by $* * *, * *$, and * respectively. Robust standard errors were in parenthesis. 
trade via GDP on environmental pollution. On the factor abundance effect $(K L * S T O)$, finding revealed less strong evidence supporting this hypothesis. The coefficient in all estimates has the expected theoretical sign but only statistically significant in model (7). This implies that there is no robust evidence that with open trade African countries explore comparative advantage in labour-intensive export and production which are less polluting. The indirect effect of trade via energy intensity is positive and statistically significant which implies that trade does not allow the use of energy-efficient technology that lowers $\mathrm{CO}_{2}$ emissions. This finding is robust to different linear and cubic polynomial models. The three mediation effects have further confirmed that services trade is more polluting in African countries. As expected the coefficient of agriculture is negative in all estimates but only statistically significant in model (8). Finding revealed little evidence that increasing the share of industry increases emissions. Contrary to our theoretical a priori we found an increasing share of services to increase carbon emissions. This finding further confirmed that services trade and the activities of the services sector are polluting in African countries. Consistent with the theoretical a priori, democratic government has a negative and statistically significant impact on carbon emissions and improves environmental quality.

\section{Robustness Check}

As a robustness check to our baseline cubic polynomial model (1) and the linear models (7)-(9) of Table 1, we used random coefficient and re-estimate the models as presented in Table 2. The RE model was chosen based on the Hausman test because the FE model cannot be consistently estimated for our panel. The empirical finding obtained from the alternative estimates is consistent with the result of the GMM estimate. This further implies that our finding is robust to different dynamic and static estimates as well as to linear and cubic polynomial models.

\section{Conclusions}

In the literature on trade and environment, several studies have thoroughly investigated the impact of goods and overall trade on environmental quality. To this end, this study deviates from previous studies and investigates both the direct and indirect effect of services trade on the environment in a panel of African countries. The empirical findings provided in this study are new to the literature. This is because the study adopted an openness index that is rarely used in trade literature which was constructed based on [11]'s approach. Findings revealed that the scale effect increases emissions while the technique effect reduces emissions and validate the EKC hypothesis.
The decrease in emissions necessitated by the technique effect is only temporary as evidenced by the positive GDP cubic component. This implies that there is an $\mathrm{N}$-shaped nexus between GDP and carbon emissions in African countries. Services trade was found to increase $\mathrm{CO}_{2}$ emissions and impede environmental quality and there is no evidence of a turning point in the services trade- $\mathrm{CO}_{2}$ emissions nexus. Finding also revealed that the composition effect increases $\mathrm{CO}_{2}$ emissions and degrades the environment. It is also found that the energy effect is positive and significant for the average African country. There is robust evidence that African countries are pollution haven when open to trade as developed countries used trade to transfer their polluting activities to the continent. Our finding revealed little evidence supporting the factor abundance effect. The mediation effect of trade via energy use is positive, indicating that trade has not allowed African countries to have access to energy-efficient technology which lowers emissions. For the control variables like democratic government, agriculture, industry, and services value-added findings revealed less strong evidence of their impact on the environmental quality indicator.

The policy implication of these findings is that, since the scale effect increases $\mathrm{CO}_{2}$ emissions and degrades the environment we, therefore, recommend the need to upgrade or replace the existing production techniques that are less efficient and more polluting with an upto-date, more efficient, and less polluting technique of production. There is also the need to reduce pressure on resource use in meeting increasing domestic and foreign demand through "reduce" "recycle" and "reuse" of material when and wherever possible. This will help in striking a balance between sustainable growth and environmental pollution in the continent. Trade openness detriment the environment in which failure to account for its specific role in generating $\mathrm{CO}_{2}$ emissions may result in poor $\mathrm{CO}_{2}$ emissions mitigation policies. We, therefore, recommend that policymakers should encourage the flow of services that are environmentfriendly and capable of decreasing $\mathrm{CO}_{2}$ emissions. The positive and detrimental effect of services trade on the environment as obtained in this study is a clear indication that environmental problems arising from increased $\mathrm{CO}_{2}$ emissions are a purely global phenomenon. In this regards an international treaty is required in addressing the carbon emissions problem rather than relying on only national and regional policies.

The composition effect degrades the environment by increasing $\mathrm{CO}_{2}$ emissions but when interacted with trade openness it reduces emissions and improves environmental quality. Therefore, this finding is more appealing to policymakers. In this regard, we acknowledged the need for policymakers to implement policies aimed at reducing protection concerning the flow of less polluting services. Since energy use increases $\mathrm{CO}_{2}$ emissions a concerted effort should 
be made to increase investment in renewable energy that is less polluting. This will reduce over-reliance on conventional non-renewable energy and help in mitigating environmental pollution. While shifting from non-renewable to renewable energy, policymakers should also make sure that renewable energy prices are reasonably lower for wider access and to reduce $\mathrm{CO}_{2}$ emissions. This can be achieved by way of renewable energy consumption subsidies, lower import duty for solar panels, electric cars, etc. Environmental policies should be implemented to make sure that activities of the services sector are less prone to environmental damages by appraising the performance of the services sector's environmentally-friendly adoption capacity. To mitigate $\mathrm{CO}_{2}$ emissions in African countries, policymakers should also adopt a mechanism of pay as you emit on polluting activities. To mitigate the flow of pollution from advanced countries environmental regulations need to be strengthened to augur well for sustainable development and prevent the activities of polluting industries. Carbon emissions taxed should be imposed on foreign affiliate companies using energyintensive equipment and subsidy should be granted to less polluting foreign affiliate's activities. The role of a democratic government in reducing $\mathrm{CO}_{2}$ emissions is less satisfactory in African countries. Therefore, policymakers should make effort in bringing active democratic freedom so that citizens' political rights can lead to an increase in people's awareness and demand for environmental quality.

\section{Acknowledgments}

The authors are very thankful to all the peer reviewers for their immeasurable inputs and comments on the improvement of this study.

\section{Conflict of Interest}

The authors declare no conflict of interest.

\section{References}

1. DU W., LI M.. Influence of Environmental Regulation on Promoting the Low-carbon Transformation of China's Foreign Trade: Based on the Dual Margin of Export Enterprise. Journal of Cleaner Production, 244 (2020), 1, 2020.

2. ANTWEILER W., COPELAND B.R., SCOTT T. Is Free Trade Good for the Environment? American Economic Review, 91 (2), 877, 2001.

3. HSU A., ESTY D.C., SHERBININ A.D., LEVY M. A. Environmental Performance Index. Yale Center for Environmental Law and Policy (YCELP) and Center for International Earth Science Information Network (CIESIN), Columbia University, 2016.

4. UNEP. Keeping Track of Our Changing Environment from Rio to Rio+20 (1992-2012). Division of Early Warning and
Assessment. United Nations Environment Programme, 2011.

5. WTO UNEP. Trade and Climate Change. World Trade Organization (WTO) Publications, 2009.

6. FIORINI M., HOEKMAN B. Services Trade Policy and Sustainable Development. World Development, 112 (2018), 1-12(2018), 2018

7. GICHERU M.N., NKEM J.N. Transforming Africa's Transport Sector with the Implementation of Intended Nationally Determined Contributions. The ClimDevAfrica Programme, Policy Brief, 2016.

8. GROSSMAN G.M., KRUEGER A.B. Economic Growth and the Environment. Quarterly Journal of Economics, 110 (2), 353, 1995.

9. UNDP. Fighting Climate Change: Human Solidarity in a Divided World, Human Development Report 2007/2008. United Nations Development Programme, World Bank Group. Palgrave Macmillan, 2007.

10. GORE A. Vice President Al Gore's Perspective on Global Warming (Issue 866), 2011

11. SQUALLI J., WILSON K. A New Measure of Trade Openness. The World Economy, 34 (10), 1745, 2011.

12. GROSSMAN G.M., KRUEGER A.B. Environmental Impacts of a North American Free Trade Agreement. NBER Working Paper Series No. 3914, 1991.

13. KELLENBERG D.K. An Empirical Investigation of the Pollution Haven Effect with Strategic Environment and Trade Policy. Journal of International Economics, 78 (2), 242, 2009.

14. COPELAND B.R., TAYLOR M.S. Trade, Growth, and the Environment. Journal of Economic Literature, 42 (1), 7, 2004.

15. NAHMAN A., ANTROBUS G. Trade and the Environmental Kuznets Curve: Is Southern Africa a Pollution Haven? South African Journal of Economics, 73 (4), 803, 2005.

16. FRANKEL J. Environmental Effects of International Trade. Sweden's Globalisation Council, Expert Report, No. 31, 2008.

17. NEMATI M., HU W., REED M. Are Free Trade Agreements Good for the Environment? A Panel Data Analysis. Review of Development Economics, 23 (1), 435, 2019.

18. HU H., XIE, N., FANG D., ZHANG X. The Role of Renewable Energy Consumption and Commercial Services Trade in Carbon Dioxide Reduction: Evidence from 25 Developing Countries. Applied Energy, 211 (2018), 1229, 2018.

19. TAMAZIAN A., CHOUSA J.P., VADLAMANNATI K.C. Does Higher Economic and Financial Development lead to Environmental Degradation: Evidence from BRIC Countries. Energy Policy, 37 (1), 246, 2009.

20. ZHANG Y., ZHANG S. The Impacts of GDP, Trade structure, Exchange rate and FDI Inflows on China's Carbon emissions. Energy Policy, 120 (2018), 347, 2018.

21. IBRAHIM K.H., SARI D.W., HANDOYO R.D. Revisiting Squalli-Wilson's Measure of Trade Openness in the Context of Services Trade. Iranian Economic Review, (In Press).

22. ACHEAMPONG A.O., ADAMS S., BOATENG E. Do Globalization and Renewable Energy contribute to Carbon emissions Mitigation in Sub-Saharan Africa? Science of the Total Environment, 677 (2019), 436, 2019.

23. HAKIMI A., HAMDI H. Trade Liberalization, FDI inflows, Environmental Quality and Economic Growth: A Comparative Analysis between Tunisia and Morocco. 
Renewable and Sustainable Energy Reviews, 58 (2016), 1445, 2016.

24. HONGLEI C., XIAORANG Z., QIUFENG C.Q. Exportoriented Economy \& Environmental Pollution in China: the Empirical Study by Simultaneous Equation Model. Energy Procedia, 5 (2011), 884, 2011.

25. KOZUL-WRIGHT R., FORTUNATO P. International Trade and Carbon Emissions. European Journal of Development Research, 24 (4), 509, 2012.

26. SHAHBAZ M., HAOUAS I., HOANG T.H. Economic Growth and Environmental Degradation in Vietnam: Is the Environmental Kuznets Curve a Complete Picture? Emerging Markets Review, 38 (2019), 1978, 2019.

27. UDEAGHA M.C., NGEPAH N. Revisiting Trade and Environment Nexus in South Africa: Fresh Evidence from New Measure. Environmental Science and Pollution Research, 26 (28), 29283, 2019.

28. ZENG B., WU T., GUO X. Interprovincial Trade, Economic Development and the Impact on Air Quality in China. Resources, Conservation \& Recycling, 142 (2019), 204, 2019.

29. KHALIL S., INAM Z. Is Trade Good for Environment? A Unit Root Cointegration Analysis. The Pakistan Development Review, 45 (4 Part II), 1187, 2006.

30. SHAHBAZ M., GOZGOR G., ADOM P.K., HAMMOUDEH S. The Technical Decomposition of Carbon Emissions and the Concerns about FDI and Trade Openness Effects in the United States. International Economics, 159 (2019), 56, 2019.

31. ACHEAMPONG A.O. Modelling for Insight: Does Financial Development Improve Environmental Quality. Energy Economics, 83 (2019), 156, 2019.

32. FARHANI S., CHAIBI A., RAULT C. $\mathrm{CO}_{2}$ emissions, Output, Energy consumption, and Trade in Tunisia. Economic Modelling, 38 (2014), 426, 2014.

33. OMRI A., DALY S., RAULT C., CHAIBI A. Financial Development, Environmental Quality, Trade and Economic Growth: What Causes What in the MENA Countries. Energy Economics, 48 (2015), 242, 2015.

34. SHAHBAZ M., KHRAIEF N., UDDIN G.S., OZTURK I. Environmental Kuznets Curve in an Open Economy: A Bounds Testing and Causality Analysis for Tunisia. Renewable and Sustainable Energy Review, 34 (2014), 325, 2014.

35. IOREMBER P.T., USMAN O., JELILOV G. Asymmetric Effects of Renewable Energy Consumption, Trade Openness and Economic Growth on Environmental Quality in Nigeria and South Africa. Munich Personal RePEc Archive, 96333, 2019.

36. IOREMBER P.T., JELILOV G., USMAN O., ISIK A., CELIK B. Correction to: The influence of renewable energy use, human capital, and trade on environmental quality in South Africa: multiple structural breaks cointegration approach. Environmental Science and Pollution (2020), 2020.

37. USMAN O., OLANIPEKUN I.O., IOREMBER P.T., ABU-GOODMAN M. Modelling environmental degradation in South Africa: the effects of energy consumption, democracy, and globalization using innovation accounting tests. Environmental Science and Pollution Research, 27 (8), 8334, 2020.

38. AWAD A. Does Economic Integration Damage or benefit the Environment? Africa's Experience. Energy Policy, 132 (2019), 991, 2019.

39. SHARIFI M., AZARBAIEJANI K. Analyzing the Interactive Relationship between Trade Liberalization,
Financial Development, Economic Growth and Quality of Environment in OPEC Member Countries. International Business Management, 10 (19), 4522, 2016.

40. COSMAS N.C., ISAAC C., MOURAD K.A. An Econometric Analysis of the Macroeconomic Determinants of Carbon dioxide Emissions in Nigeria. Science of the Total Environment, 675 (2019), 313, 2019.

41. IOREMBER P.T., GOSHIT G.G., DABWOR D.T. Testing the nexus between renewable energy consumption and environmental quality in Nigeria: The role of broad-based financial development. African Development Review, 32 (2), 163, 2020.

42. ASGHARI M. The Stringency of Environmental Regulations and Technological Change: A Specific Test of the Porter Hypothesis. Iranian Economic Review, 5 (27), 95, 2010.

43. SHAHBAZ M., NASREEN S., AHMED K., HAMMOUDEH S. Trade Openness-Carbon Emissions Nexus: The Importance of Turning Points of Trade Openness for Country Panels. Energy Economics, 61 (2017), 221, 2017.

44. KELLENBERG D.K. A Reexamination of the Role of Income for the Trade and Environment Debate. Ecological Economics, 68 (1-2), 106, 2008.

45. LI Z., XU N., YUAN J. New Evidence on TradeEnvironment Linkage via Air Visibility. Economic Letters, 128 (2015), 72, 2015.

46. MANAGI S. Trade Liberalization and the Environment: Carbon Dioxide for 1960-1999. Economics Bulletin, 17 (1), 1, 2004.

47. USMAN O., IOREMBER P.T., OLANIPEKUN I.O. Revisiting the environmental Kuznets curve (EKC) hypothesis in India: The effects of energy consumption and democracy. Environmental Science and Pollution Research, 26 (13), 13390, 2019.

48. TAYEBI S.K., YOUNESPOUR S. The Effect of Trade Openness on Environmental Quality: Evidence from Iran's Trade Relations with the Selected Countries of the Different Blocks. Iranian Economic Review, 16 (32), 19, 2012.

49. LIOBIKIENĖ G., BUTKUS M. Scale, Composition, and Technique effects through which the Economic Growth, Foreign Direct Investment, Urbanization, and Trade affect Greenhouse gas Emissions. Renewable Energy, 132 (2019), 1310-1322, 2019.

50. LE T.-H., CHANG Y., PARK D. Trade Openness and Environmental Quality: International Evidence. Energy Policy, 92 (2016), 45, 2016.

51. CHINTRAKARN P., MILLIMET D.L. The Environmental Consequences of Trade: Evidence from Subnational Trade Flows. Journal of Environmental Economics and Management, 52 (1), 430, 2006.

52. CETIN M., ECEVIT E., YUCEL A.G. The Impact of Economic Growth, Energy Consumption, Trade Openness, and Financial Development on Carbon emissions: Empirical Evidence from Turkey. Environmental Science and Pollution Research, 25 (36), 36589, 2018.

53. HALICIOGLU F. An Econometric Study of $\mathrm{CO}_{2}$ Emissions, Energy Consumption, Income and Foreign Trade in Turkey. Energy Policy, 37 (2009), 1156. 2009.

54. JAYANTHAKUMARAN K., VERMA R., LIU Y. $\mathrm{CO}_{2}$ Emissions, Energy Consumption, Trade and Income: A Comparative Analysis of China and India. Energy Policy, 42 (2012), 450, 2012.

55. LV Z., XU T. Is Economic Globalization Good or Bad for the Environmental Quality? New Evidence from Dynamic 
Heterogeneous Panel Models. Technological Forecasting \& Social Change, 137 (2018), 340, 2018.

56. REN S., YUAN B., MA X., CHEN X. The Impact of International Trade on China's Industrial Carbon Emissions since its Entry into WTO. Energy Policy, 69 (2014), 624, 2014.

57. BERNARD J., MANDAL S.K. The Impact of Trade Openness on Environmental Quality: An Empirical Analysis of Emerging and Developing Economies. In Proceedings of the 3rd International Conference on Environmental and Economic Impact on Sustainable Development (EID 2016). Vol. 203, WIT press, 2016.

58. PAL D., MITRA S.K. The Environmental Kuznets Curve for Carbon Dioxide in India and China: Growth and Pollution at Crossroad. Journal of Policy Modeling, 39 (2017), 371, 2017.

59. CHEN Y., WANG Z., ZHONG Z. $\mathrm{CO}_{2}$ emissions, Economic growth, Renewable and Non-renewable Energy Production and Foreign Trade in China. Renewable Energy, 131 (2019), 208, 2019.

60. SINHA A., GUPTA M., SHAHBAZ M., SENGUPTA T. Impact of Corruption in Public Sector on Environmental Quality: Implications for Sustainability in BRICS and next 11 countries. Journal of Cleaner Production, 232 (2019), 1379, 2019.

61. JAVID M., SHARIF F. Environmental Kuznets Curve and Financial Development in Pakistan. Renewable and Sustainable Energy Reviews, 54 (2016), 406, 2016.

62. BOUTABBA M.A. The Impact of Financial Development, Income, Energy and Trade on Carbon emissions: Evidence from the Indian economy. Economic Modelling, 40 (2014), 33, 2014.

63. LIN F. Trade openness and Air Pollution: City-level Empirical Evidence from China. China Economic Review, 45 (2017), 78, 2017.

64. SABOORI B., SULAIMAN J.B., MOHD S. An Empirical Analysis of the Environmental Kuznets Curve for $\mathrm{CO}_{2}$ Emissions in Indonesia: The Role of Energy Consumption and Foreign Trade. International Journal of Economics and Finance, 4 (2), 243, 2012.

65. WANG S., WANG X., TANG Y. Drivers of Carbon Emission Transfer in China-An Analysis of International Trade from 2004 to 2011. Science of the Total Environment, 709 (2020), 1, 2020.

66. ZHANG J. International Production Fragmentation, Trade in Intermediate Goods and Environment. Economic Modelling, 87 (2020), 1, 2020.

67. FAN X., WU S., LI S. Spatial-temporal Analysis of Carbon emissions Embodied in Interprovincial Trade and Optimization Strategies: A Case Study of Hebei. China. Energy, 185 (2019), 1235, 2019.

68. WANG Z., LI C., LIU Q., NIU B., PENG S., DENG L., ZHANG X. Pollution Haven Hypothesis of Domestic Trade in China: A Perspective of $\mathrm{SO}_{2}$ Emissions. Science of the Total Environment, 663 (2019), 198, 2019.

69. LIA J.S., CHEN G.Q., CHEN B., YANG Q., WEI W.D., WANG P., CHEN H.P. The Impact of Trade on Fuel-related Mercury Emissions in Beijing - Evidence from ThreeScale Input-Output Analysis. Renewable and Sustainable Energy Reviews, 75 (2017), 742, 2017.

70. TIAN X., HU Y., YIN H., GENG Y., BLEISCHWITZ R. Trade Impacts of China's Belt and Road Initiative: From Resource and Environmental Perspectives. Resources, Conservation \& Recycling, 150 (2019), 1, 2019.

71. ARELLANO M., BOND S. Some Tests of Specification for Panel Data: Monte Carlo Evidence and an Application to Employment Equations. Review of Economic Studies, 58 (2), 277, 1991.

72. BLUNDELL R., BOND S. Initial Conditions and Moment Restrictions in Dynamic Panel Data Models. Journal of Econometrics, 87 (1), 115, 1998.

73. BOND S., HOEFFLER A., TEMPLE J. G Assalamu'alaikum waramatullah. Good evening Sir. MM Estimation of Empirical Growth Models. Economics Group, Nuffield College, University of Oxford. Economics Papers 2001-W21, 2001. 